Issues That Impact U.S.

Asian/Pacific Islander

Adults Age 45 and Older,

November 2020

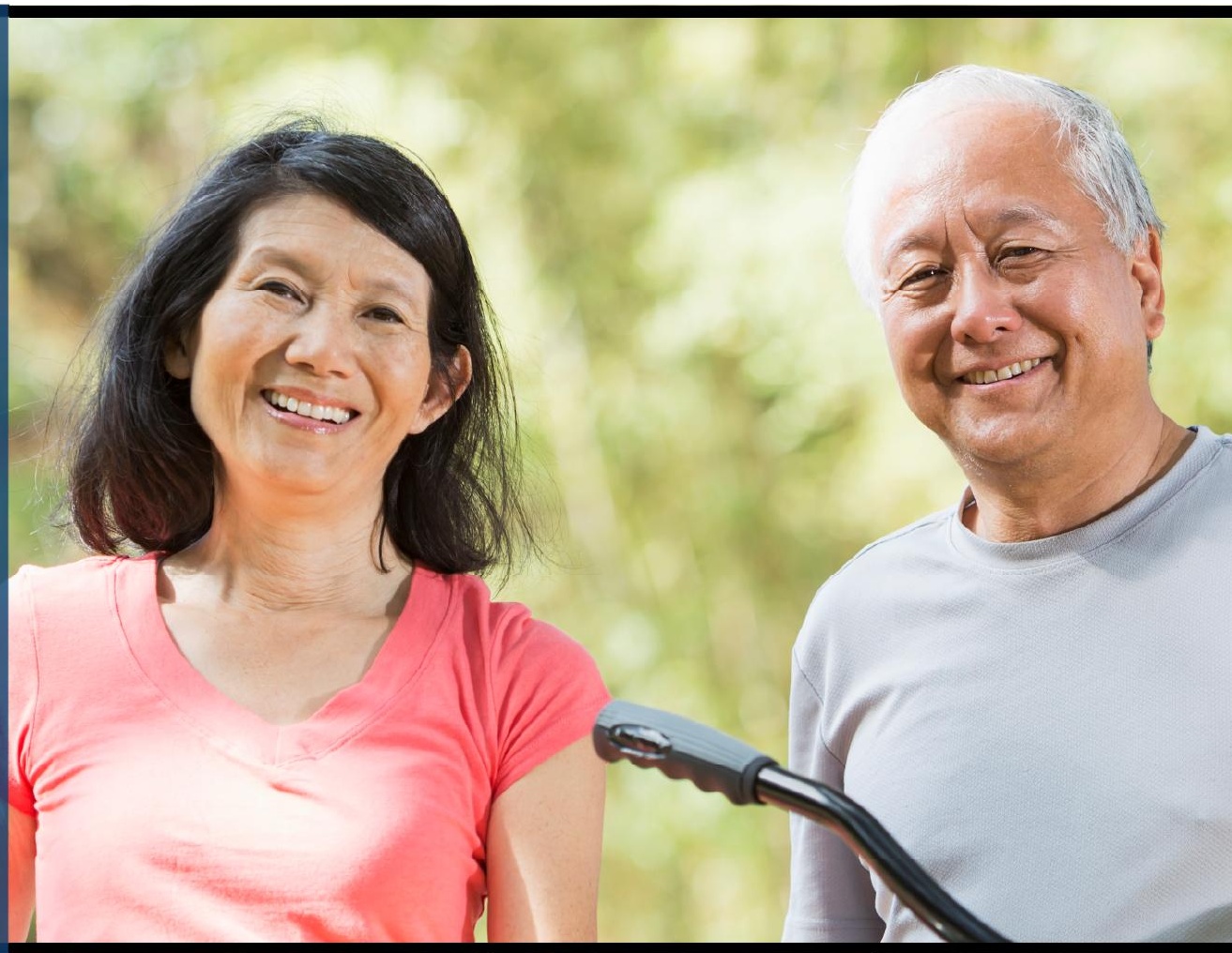

Issues of Importance to U.S. Asian/Pacific Islander Adults Age 45+

\section{Health Care}

Staying physically
healthy

Staying mentally sharp

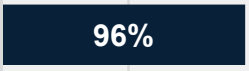

Adequate health insurance coverage

\section{Medicare benefits available in the future}

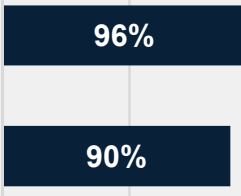

Paying for health care expenses

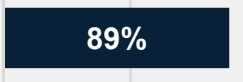

Paying for prescription drugs

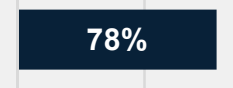

$0 \%$

$50 \% \quad 100 \%$

\section{Economic/Financial}

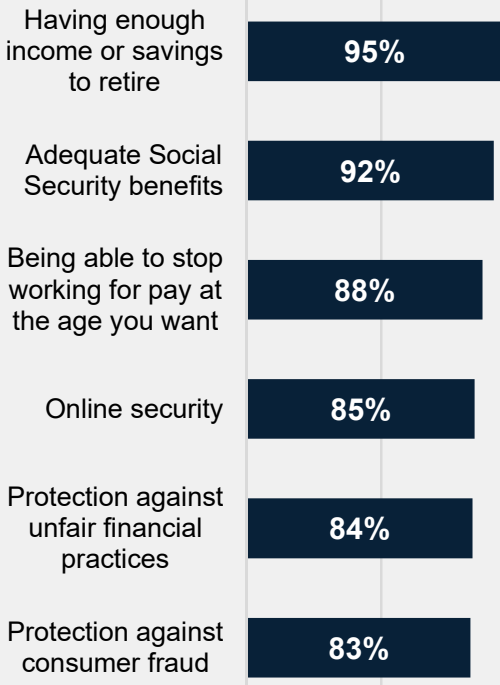

$0 \%$

\section{Independent Living/ Long-Term Care}

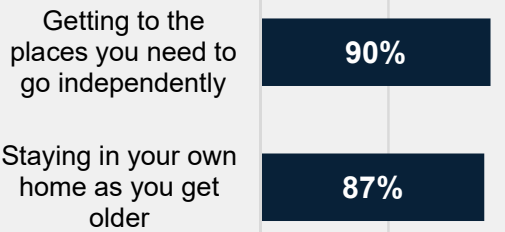

Caring for a loved
one

$83 \%$

Having high quality long-term care

\section{$82 \%$}

Having alternatives to nursing home care

\section{$77 \%$}


Interviews were conducted with 403 U.S. Asian/Pacific Islander adults by cell phone (60\%) and online (40\%) between November 13, 2020 and November 29, 2020.

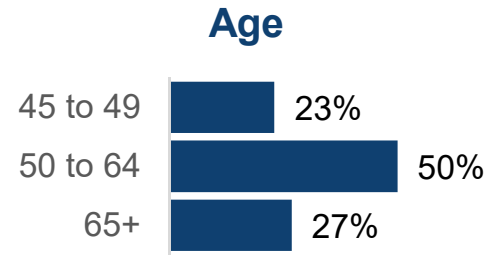

\section{Employment}

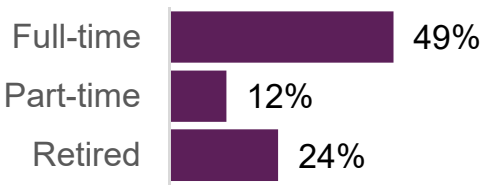

\section{Gender}

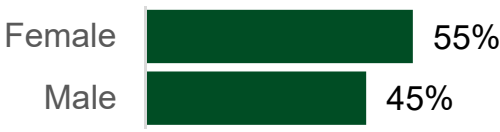

Education

Some college or less

4-year college degree

Post-graduate study or degree

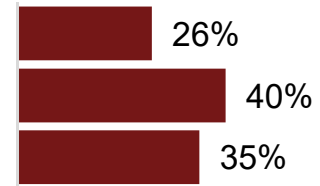

\section{Marital Status}

Married/ living with partner

Divorced/ separated

Widowed

Never married

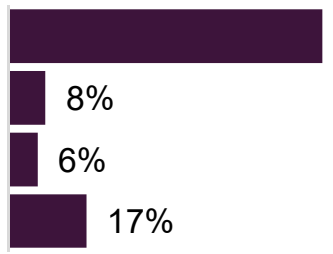

$69 \%$

\section{Annual Household Income}

Less than $\$ 50,000$

$\$ 50,000$ to less than $\$ 100,000$

$\$ 100,000+$

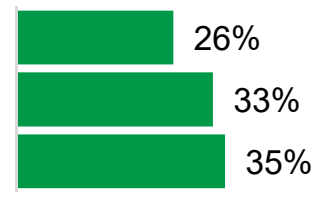

Race/Ethnicity
$100 \%$

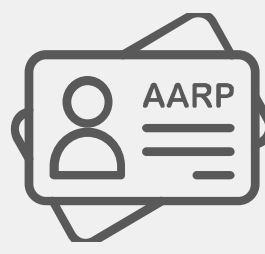

$27 \%$

AARP Member

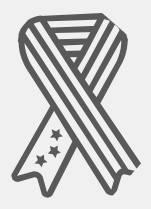

$7 \%$

Veteran 